
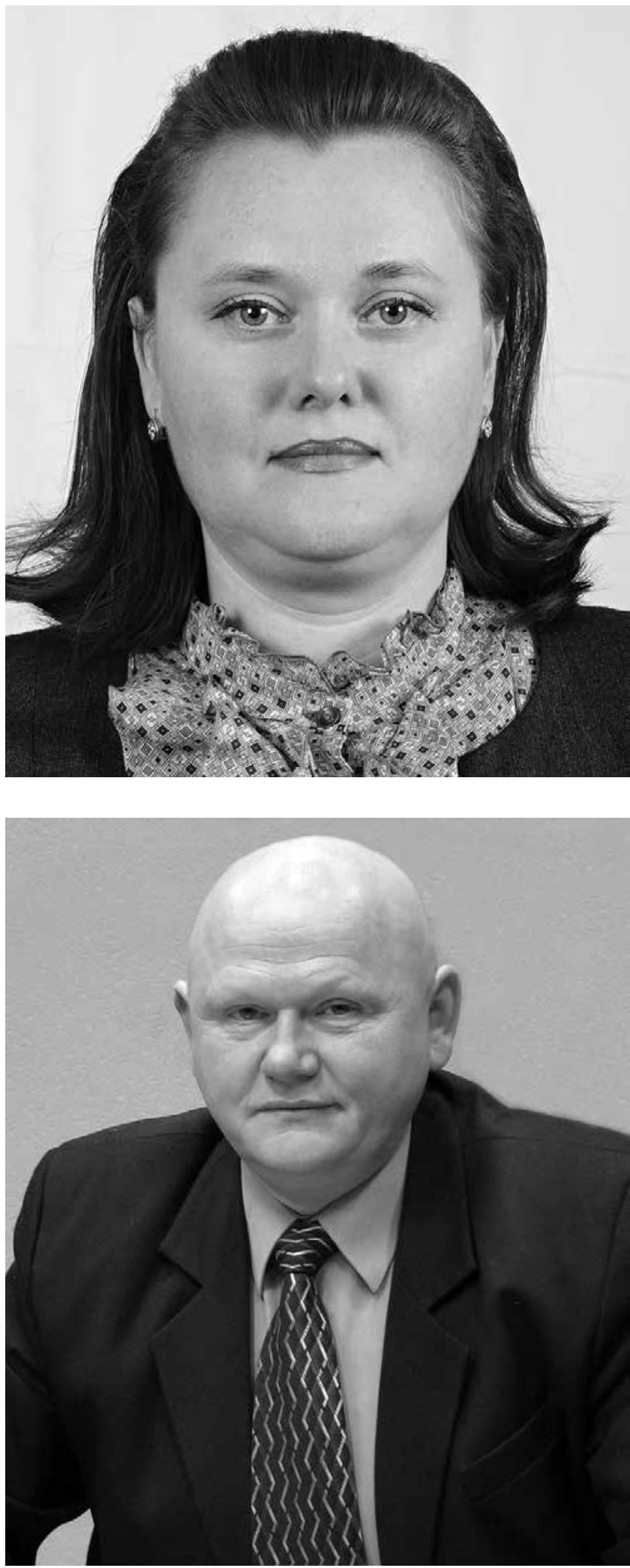

\section{УДК 35.078+351(477)}

https://doi.org/10.32689/2617-2224-2021-2(27)-6

\section{Сидоренко Наталя Олегівна,}

кандидат наук з державного управління, доцент кафедри менеджменту, Інститут підготовки кадрів державної служби зайнятості України, 03038, м. Київ, вул. Нововокзальна, 17, e-mail: sidnat@ukr.net, https://orcid.org/0000-0001-8734-9704

\section{Sydorenko Natalya Olehivna,}

Candidate of Sciences in Public Administration, Associate Professor at the Management Department, Ukrainian State Employment Service Training Institute, 03038, Kyiv, Novovokzalna str., 17, e-mail: sidnat@ukr.net, https://orcid.org/0000-0001-8734-9704

\section{Шкурат Іван Вікторович,}

доктор наук з державного управління, доцент кафедри менеджменту, Інститут підготовки кадрів державної служби зайнятості України, 03038, м. Київ, вул. Нововокзальна, 17, e-mail: ishiva@ukr.net, https://orcid.org/0000-0002-8810-2890

\section{Shkurat Ivan Viktorovych,}

Doctor of Science in Public Administration, Associate Professor at the Management Department, Ukrainian State Employment Service Training Institute, 03038, Kyiv, Novovokzalna str., 17, e-mail: ishiva@ukr.net, https://orcid.org/0000-0002-8810-2890

\title{
ІНОЗЕМНИЙ ДОСВІД У СФЕРІ НАДАННЯ АДМІНІСТРАТИВНИХ ПОСЛУГ
}

Анотація. Мета роботи полягає у дослідженні іноземного досвіду надання адміністративних послуг та обгрунтуванні можливості його впровадження у вітчизняних умовах. Встановлено, що надання адміністративних послуг у закордонних країнах і Україні відрізняється за суттю та метою роботи. Система надання адміністративних послуг у розглянутих країнах (Франції, Німеччині, 
Нідерландах, Бельгії, Польщі, Великобританії, Естонії, Норвегії, Канаді та Болгарії) спрямована на забезпечення населення усіма видами соціальних гарантій. Враховуючи світовий досвід, можна стверджувати, що надання адміністративних послуг в закордонних країнах є відкритим та прозорим процесом, а в Україні досі немає таких ефективних взаємовідносин між споживачами та надавачами адміністративних послуг. Методологія. У процесі написання даної статті були використані такі методи: групування, систематизація та узагальнення, системний та комплексний підходи. Наукова новизна дослідження полягає в удосконаленні наявних та розробленні нових заходів покращення надання адміністративних послуг населенню в Україні. Висновки. Зважаючи на світовий досвід, на нашу думку, щоб покращити сферу надання адміністративних послуг в Україні, варто вжити таких заходів: розширити перелік адміністративних послуг у сфері соціального забезпечення та ЖКГ; розширити реєстр інституцій, які надають адміністративні послуги, включаючи не лише окремі органи державної влади та місцевого самоврядування, а й приватні заклади (шляхом надання дозволу на таку діяльність); зменшити розбіжності між адміністративними послугами та послугами, які надаються приватними суб'єктами; поглибити децентралізаційні процеси та делегувати права для прийняття рішень місцевим органам влади; ввести використання електронної форми надання адміністративних послуг; забезпечити довіру та безпеку споживачів адміністративних послуг, які отримують дану послугу в онлайн-режимі; покращити сервіси контролю за якістю надання адміністративних послуг, зважаючи на думку громадськості та безперервний контроль з боку публічних адміністрацій.

Ключові слова: адміністративні послуги, державні та місцеві органи влади, органи публічної влади, е-урядування, офіс для громадян, універсам послуг.

\section{FOREIGN EXPERIENCE IN THE FIELD OF PROVISION OF ADMINISTRATIVE SERVICES}

Abstract. The purpose of the research is to study the foreign experience in providing administrative services and justify the possibility of its implementation in the domestic environment. It is established that the provision of administrative services in foreign countries and Ukraine differs in the nature and purpose of their work. Typically, the system of administrative services in the above countries (France, Germany, the Netherlands, Belgium, Poland, Great Britain, Estonia, Norway, Canada and Bulgaria) is aimed at providing the population with all kinds of social guarantees. Given the world experience, it can be argued that the provision of administrative services in foreign countries is an open and transparent process, and in Ukraine there is still no such effective relationship between consumers and providers of administrative services. Methodology. In the process of writing this article, the following methods were used: grouping, systematization and generalization, system and integrated approaches. Scientific novelty of the research results is the improvement of existing and development of new measures to improve the provision of administrative services to the population in Ukraine. Conclusions. Given the world experience, in our opinion, Ukraine should: expand the list of administrative services in the field of social security and housing; to expand the register of institutions that provide administrative services, including not only individual bodies of state power and local self-government, but also private institutions by granting permission for such activities; reduce discrepancies between administrative services and services provided by private entities; deepen decentralization processes and delegate decision-making rights to local authorities; introduce the use of electronic forms of administrative services; to ensure the trust and security of consumers of administrative services who receive this service online; improve quality control services for the provision of administrative services, taking into account public opinion and continuous monitoring by public administrations.

Key words: administrative services, state and local authorities, public authorities, e-government, office for citizens, service universities.

\section{1. Вступ}

Для ефективного розвитку публічного управління в Україні доволі важливо віднайти нові й сучасні механізми. Нині існує чимало проблемних питань, пов'язаних із величезними чергами у ЦНАПах, великим різноманіттям платежів та безмежними візитами до урядових кабінетів. 3 огляду на це сьогодні в нашій державі реалізується чимало реформ, зокрема і у сфері надання адміністративних послуг насе- 
ленню. Крім цього, докладається чимало зусиль для покращення комунікаційних зв'язків громадян $з$ державою, які своєю чергою виступають споживачем та надавачем адміністративних послуг. Беручи до уваги все зазначене, можна стверджувати, що дослідження кращої іноземної практики надання адміністративних послуг населенню є доволі актуальним.

Сфера надання адміністративних послуг населенню в зарубіжних країнах формувалася протягом досить тривалого часу. Найважливішим індикатором, що дозволяє визначати ефективність надання таких послуг, вважається рівень їх якості, який оцінюють безпосередньо їх споживачі.

3 огляду на це сьогодні доволі актуальним $€$ вивчення найкращого світового досвіду надання адміністративних послуг населенню (зокрема, Франції, Німеччини, Нідерландів, Бельгії, Польщі, Великобританії, Естонії, Норвегії, Канади та Болгарії). Нині неоднозначно розцінюється необхідність впровадження світового досвіду у сферу надання адміністративних послуг в Україні. Цю сферу в нашій державі можна удосконалити та наблизити до стандартів $\mathrm{CC}$, а не ігнорувати як архаїчну. Так, доволі багато науковців-спеціалістів, які тривалий час досліджують сферу надання адміністративних послуг, стверджують, що Україні вкрай необхідно покращити комунікаційні зв'язки з європейськими державами стосовно дослідження та впровадження в практичну роботу кращого іноземного досвіду надання адміністративних послуг.

Дослідженням світового досвіду адміністративних послуг займалися такі науковці, як О.М. Андрєєва, Н.В. Васильєва, М.I. Лахижа, Р.А. Омельянович, Д.В. Спасібов, В. Тимощук, О.К. Туркова, Д.С. Тихонова, О.Г. Циганов, А.О. Чечель, М. Шкільняк та інші.

Мета статті полягає у дослідженні іноземного досвіду надання адміністративних послуг 3 переважним використанням компаративного методу та обгрунтуванні можливості його впровадження у вітчизняних умовах.

\section{2. Франція}

У Франції були створені інноваційні Центри публічних служб, у яких зосереджені послуги, що належать до компетенції різних установ, зокрема, органів місцевого самоврядування та приватних організацій, що працюють за державним замовленням, державних агентств, соціальних органів (Циганов, 2017). Їх спільні риси такі: постійне підвищення якості послуг, що надаються; концентрація більшості затребуваних послуг в одному місці; вибір місця розташу- вання центрів послуг на основі доступності та зручності для відвідувачів; формування графіка роботи центрів, який був би зручним для відвідувачів; створення зручних умов для громадян, які перебувають в універсамі послуг; забезпечення спеціальних умов для осіб із обмеженими фізичними можливостями; формування систем е-урядування для отримання великої кількості послуг у онлайн-режимі. Загальнодержавний портал надання послуг протягом місяця відвідує понад чотири мільйони користувачів (Спасібов, 2018).

\section{3. Німеччина}

Найважливіша ознака сфери адміністративних послуг Німеччини полягає в існуванні кодифікованого акта, який регулює роботу публічних органів, зокрема й тих, які надають дані послуги. Перед створенням офісів для громадян (універсамів послуг) у Німеччині доволі активно і грунтовно досліджувався досвід Нідерландів.

Структура та організація універсамів послуг у Німеччині передбачає:

- організацію великого офісного приміщення з місцями обслуговування замовників (зокрема, для конфіденційних розмов);

- створення фронт-офісу (зони обслуговування замовників) та бек-офісу (зони для роботи співробітників УП), де опрацьовуються документи, розподіляється пошта, працює телефонна служба;

- широку компетенцію працівників, яка полягає у тому, що усі послуги повинні опрацьовуватися в УП всіма співробітниками (принцип загальних повноважень або універсалізму);

- УП у порівняно великих містах (понад 30000 жителів) мають біля входу інфотеки, де замовники отримують інформацію та вирішують дрібні питання (отримують бланки заяв, забирають готові посвідчення особи). Така організаційна форма сприяє скороченню часу прийому та регулює потоки відвідувачів);

- якщо деякі місця обслуговування відвідуються споживачами частіше, то рекомендується періодично (щотижня) практикувати зміну робочих місць між співробітниками (принцип ротації), що сприяє збалансованому розподілу навантаження та урізноманітненню сфер діяльності працівників;

- починаючи з певного розміру міста (понад 40000 жителів), черга регулюється різними системами організації прийому (системою талонів з номерами). Необхідність впорядкування черги, крім іншого, зумовлюється відсутністю у споживачів можливості бачити усі місця обслуговування; 
- організацію позмінної роботи через подовжені години прийому 3 тією метою, щоб у години-пік була забезпечена достатня чисельність персоналу. Отже, працівники бюро для громадян працюють не відповідно до загального режиму роботи в органах місцевого самоврядування, аджеїм надається можливість колективно вирішувати питання режиму роботи (складати робочий графік) (Тимощук, 2012).

Сьогодні таких офісів лише у Берліні є 46 . Вони вважаються своєрідною візитівкою адміністрації (віддзеркалюють iï репутацію серед населення) та передбачають трансформацію владних органів на установи з надання послуг на базі єдиного офісу для населення, де люди мають змогу отримати послуги швидко після першого ж візиту. Варто зазначити, що сьогодні громадяни Німеччини можуть отримати понад 170 видів онлайн-послуг.

Проте, незважаючи на доволі тривалий період, потягом якого було прийнято чимало ініціатив, стратегій та законів, що сприяють електронному уряду та цифровізації, прогрес електронного уряду є помірним, адже Німеччина явно відстає від багатьох інших країн $\mathrm{CC.}$ У більшості порівнянь Німеччина має середній рейтинг. Відсутність прогресу щодо цифровізації електронного урядування також широко розглядається політиками та державним управлінням. Навіть Національна рада регуляторів дійшла висновку, що в Німеччині електронне урядування у сфері надання адміністративних послуг де-факто не існує (Nationaler Normenkontrollrat, 2016). Ключовими причинами повільного прогресу є відсутність ефективного управління та фінансування федерального устрою. На даний момент більшість штатів та органів місцевого самоврядування мають власні IT-структури з обмеженою координацією та співпрацею між ними.

\section{4. Нідерланди}

На думку чималої кількості як іноземних, так і вітчизняних науковців, нідерландська система офісів для громадян (універсамів послуг) $€$ найкращою серед інших європейських країн. До їі складу входить модель, яка складається 3 двох рівнів. Так, до першого рівня входить центральний офіс для громадян міста. До другого рівня входять універсами послуг у районах міста. Певні види адміністративних послуг громадяни Нідерландів можуть отримати тільки в центральному офісі, а деякі - у районах міста. Це залежить від їх складності та частоти їх затребуваності. Подібна модель дає можливість забезпечити високий рівень ефективності роботи системи надання адміністративних послуг шляхом розподілу виробничих засобів та їх наближеності до споживачів залежно від необхідності. На нашу думку, саме нідерландська система офісів для громадян (універсамів послуг) є доволі актуальною в умовах сьогодення в Україні та практично набуває впровадження у вигляді розбудови ЦНАПів у містах на регіональному та районному рівнях.

\section{5. Бельгія}

У Бельгії усю потрібну документацію громадяни мають можливість подати дистанційно через комп'ютер. Для цього вони повинні мати персональну карту, за допомогою якої можна певні персональні дані не заносити до визначених форм, а завантажити із загальної бази. Так, громадяни Бельгії мають можливість дистанційно отримати довідку про місце проживання, довідку про склад сім'ї, карту місцевого жителя, поліцейські витяги, паркувальні талони, свідоцтво про народження, шлюб, розлучення тощо (Спасібов, 2018).

\section{6. Польща}

У Польщі створення єдиних офісів, які надають адміністративні послуги, розпочалося у кінці 90-х років разом із адміністративно-територіальним реформуванням, яке було спрямоване на перерозподіл функцій, пов'язаних із наданням адміністративних послуг, між територіальними громадами. Воно призвело до передачі близько 63\% підрозділів державного сектору муніципальному сектору, підпорядкованому новоствореним підрозділам місцевого самоврядування. Функція державного управління була змінена. У своїй новій формі вона повинна була зосередити увагу на пріоритеті таких дій, як формулювання політики і створення розробки стратегії. Муніципальний сектор повинен був надавати державні послуги відповідно до узгодженого стандарту. Після адміністративної реформи 1998 р. розпочався процес адаптації сучасних методів управління.

Механізм надання публічних послуг у Польщі характеризується тим, що кожна послуга, яку надає воєводська адміністрація, відповідно задокументована. Наприклад, карта послуги «видання паспортів» містить такі основні дані: документи, які повинна подати особа 3 метою оформлення паспорта, плата, адреса та дані відповідальної особи, місце оформлення та отримання, телефон, можливість подання скарг і пропозицій, правові підстави та рекомендації клієнту. У Польщі саме субсидіарність (наділення максимальною компетенцією органу, 
який є ближчим до громадян) вважають основним принципом надання публічних послуг громадянам. Також важливими принципами є дотримання унітарного характеру держави та компліментарність (взаємозв'язок і взаємодоповнення органів влади) (Чечель, 2021).

Отже, найважливіше завдання територіальних органів влади в Польщі полягає в організації надання адміністративних послуг населенню. Владні органи зобов'язані організувати надання різних видів публічних послуг, проте не зобов'язані безпосередньо їх надавати. Переважно з цією метою укладають договори із підприємствами або неурядовими установами.

\section{7. Великобританія}

У Великій Британії діє об’єднаний ресурс адміністративних органів, за допомогою якого можна отримати онлайн-послуги, згруповані для зручності користування у такі групи: отримання пільг; реєстрація народжень, смертей, шлюбів; послуги у сфері бізнесу та підприємців; послуги щодо отримання громадянства або права на постійне проживання у Великій Британії; послуги у сфері політичних прав; послуги у сфері судів та поліції; окрема група послуг для людей із обмеженими фізичними можливостями; послуги у сфері права власності; послуги у сфері імміграції; окрема група послуг, які стосуються трудових прав громадян (Тихонова, 2014).

Одним із елементів організації публічних послуг, що належать до місцевого самоврядування, є система "Best Value" («Найкраща якість»), яка втілюється у життя 32000 р. i передбачає обов'язок надання послуг згідно з ясними стандартами, які включають як вартість, так і якість, за допомогою найбільш ефективних, економічних та продуктивних засобів. Ключовою частиною цієї системи є визначення точних показників ефективності використання та цілей конкретних місцевих послуг (Шкільняк, 2003).

На нашу думку, практика Великої Британії у сфері покращення якості надання адміністративних послуг на сьогоднішній день відіграє доволі важливу роль, оскільки значення рад є фундаментальним в процесі забезпечення достатньої якості надання послуг населенню. Основоположними у Великобританії виступають місцеві угоди адміністративних послуг, головна мета яких полягає не лише у посиленні рад із надання адміністративних послуг територіальним громадам, але й у покращенні індикаторів, які використовуються для оцінювання діяльності таких рад.

\section{8. Естонія}

Після одержання незалежності перед Естонією постало одне з найголовніших завдань, яке полягало у подоланні спадку минулого, знищенні бюрократизму та надмірної документації. Розв'язання даного завдання передбачало тісну комунікацію між споживачами адміністративних послуг та органами публічного управління. Наслідком цього стало запровадження в країні проєкту «Електронна Естонія». Це вимагало перегляду та оптимізації чисельності послуг та формування централізованої бази таких послуг. Водночас відбулося створення ЦНАП на основі принципу єдиного вікна, що сприяло автоматизації процесу обслуговування населення. У результаті цього публічні органи влади одержали ефективний інструментарій обслуговування населення в електронному вигляді, а процедури стали потребувати суттєво менших часових затрат. Отже, громадяни Естонії сьогодні отримують адміністративні послуги в електронному вигляді, що регулюється належним нормативно-правовим забезпеченням. Варто зазначити, що електронні процедури ототожнюються зі стандартними процедурами 3 особистими контактами та бюрократичним документообігом.

У створенні сучасної електронної системи в Естонії фундаментальним елементом новацій була електронна ID-карта. Ця карта стала обов'язковим документом для ідентифікації особистості громадянина. У цьому виді документу знаходиться спеціальна мікросхема, на якій розміщено інформацію стосовно його власника, ідентифікатор особистості та власний електронний підпис. Така ID-карта забезпечена високим рівнем захисту, до того ж вона дає можливість громадянину скористатися різноманітними інтернет-сервісами, котрі значно спрощують сервісне забезпечення. Фактично це заміна звичного для українців паспорта, що забезпечує налагодження взаємин громадянина із органами влади та дозволяє отримати доступ до органів публічного управління та різноманітних публічних послуг. Слід відзначити й залучення до процесу надання адміністративних послуг електронних гаджетів, зокрема мобільних телефонів, через які дається доступ до послуг за умови підтвердження особистості шляхом введення власного пін-коду (Васильєва, 2013).

Водночас із використанням новацій для бізнесу в Естонії приділяється значна увага послугам для пересічних громадян. Серед них дослідниками виділяються такі: 
1) Е-поліція (отримання через електронну пошту квитанцій на оплату штрафів за порушення правил дорожнього руху);

2) Е-школа (електронний щоденник, який дозволяє налагодити зв'язок шкільної адміністрації з батьками учнів, включає розклад занять, отримані учнями оцінки, а також домашні завдання);

3) Е-депозитарій (централізований реєстр усіх акціонерних товариств у країні та цінних паперів);

4) Е-пенсія (електронна система обслуговування фізичних осіб з питань отримання пенсій, вибору пенсійних фондів, обміну звітністю тощо);

5) ID-білет (сервіс продажу квитків на муніципальний транспорт, відвідування закладів культури тощо) (Туркова, 2016).

Отже, найголовніший успіх сучасної системи публічного управління в Естонії полягає в тому, що в країні докладається чимало зусиль для забезпечення максимального сприяння бізнес-ініціативам активних громадян. За рахунок цього в Естонії стало можливо забезпечити суспільні потреби, а також досить високий економічний розвиток економіки країни в цілому. Кожна людина, яка прагне розпочати власну підприємницьку діяльність, має можливість зареєструвати свій бізнес віддалено через комп'ютер, а не вистоювати величезні черги до чиновницьких кабінетів.

\section{9. Норвегія}

У Норвегії функціонує загальнодержавний сервіс надання е-послуг населенню, за допомогою якого можна отримати велику кількість послуг, згрупованих відповідно до життевих ситуацій. Це такі ситуації, як народження дитини й оформлення батьківства, смерть і успадкування, одруження, оформлення розлучення, зміна місця проживання тощо. Відповідні е-сервіси надання послуг має кожен муніципалітет Норвегії, який можна знайти за допомогою спеціального ресурсу. Згідно з програмою розвитку е-урядування «Цифрові послуги в публічному секторі» головними цілями уряду Норвегії нині є такі: сфера публічного управління повинна бути доступною онлайн настільки, наскільки це можливо; вебсервіси повинні стати загальним правилом і засобом комунікації держави, громадян і бізнесу; максимальне вдосконалення сервісів; оцифрування сфери публічного управління повинно сприяти вивільненню ресурсів, необхідних для інших сфер (Андрєєва, 2014).

\section{0. Канада}

Протягом останніх тридцяти років у Канаді різні публічні органи на всіх рівнях влади - федеральному, провінційному та муніципальному - приділяють чимало уваги розв'язанню проблем, пов'язаних із наданням адміністративних послуг.

Нині загальними напрямами політики Канади у сфері послуг є такі: інтеграція баз даних (при цьому доступ до персональних даних клієнтів є захищеним законом і детально регламентується); інтеграція каналів доступу за послугами (один вебсайт, один довідковий/ контактний номер телефону, спільний офіс із надання послуг); спрощення процедур (зменшення розмаїття у формах заяв тощо); проактивна роль адміністрації (якщо особа, отримуючи одну послугу, має право на інші послуги, то орган влади інформує іiї про ці права або ж сам виконує активні дії для надання послуг. Наприклад, під час реєстрації народження особи батькам запропонують також зареєструвати дитину і в системі медичного страхування, проінформують про програми з виплати певних коштів на дитину тощо). Також вважається, що потрібно завчасно інформувати клієнтів про очікувані ситуації / послуги (наприклад, про наближення права на пенсію, про потребу продовжити якийсь дозвіл тощо) (Жук, 2016).

Сьогодні Канада здійснює доволі ефективну державну політику, яка відводить важливу роль створенню інтегрованих (єдиних) офісів, у яких громадяни будуть мати можливість одержати чималу кількість адміністративних послуг. Іншими словами, публічні органи різних рівнів влади намагаються об'єднатися в процесі надання публічних послуг, наприклад, створюючи колективні офіси. Такі інтегровані офіси $€$ аналогом вітчизняного ЦНАПу. Створення подібних офісів у Канаді було спочатку так званим пілотним проєктом, проте, на думку місцевих мешканців, даний проєкт є доволі вдалим. Формування списку надаваних адміністративних послуг в такому інтегрованому офісі відбувалося за результатами угоди між трьома рівнями влади.

\section{1. Болгарія}

Розбудову сучасного механізму надання адміністративних послуг у Болгарії було розпочато наприкінці 1990-х років після прийняття Стратегії створення сучасної адміністративної системи Республіки Болгарія. Цим нормативноправовим актом було зазначено таке: необхідність підвищення якості надання адміністративних послуг населенню через впровадження механізмів ринкової економіки; делегування приватним структурам повноважень з обслуговування споживачів за умов збереження контр- 
ольних функцій органів публічної влади; введення в дію новітніх технологій та забезпечення якості обслуговування. Водночас почалося впровадження системи надання послуг за принципом єдиного вікна з метою створення сприятливих умов для задоволення потреб споживачів адміністративних послуг. Вже у 2002 році урядом Болгарії затверджено Концепцію покращення адміністративного обслуговування в контексті принципу «єдине вікно». Даним документом регламентувалися такі напрями діяльності: створення загальної стратегії розвитку системи надання адміністративних послуг; вироблення загальних принципів функціонування універсаму послуг; забезпечення сприятливих умов для розбудови ефективної міжвідомчої комунікації; полегшення умов для ведення бізнесу; введення в повсякденну практику органів влади електронного урядування (Лахижа, 2013).

\section{2. Висновки}

Отже, беручи до уваги все зазначене, можна дійти висновку, що надання адміністративних послуг в закордонних країнах і в Україні відрізняється за суттю та метою роботи. Система надання адміністративних послуг у розглянутих вище країнах (Франції, Німеччині, Нідерландах, Бельгії, Польщі, Великобританії, Естонії, Норвегії, Канаді та Болгарії) спрямована на забезпечення населення усіма видами соціальних гарантій.

Нині в Україні діяльність подібної системи базується переважно на забезпеченні державного контролю над населенням, а вже після цього й на забезпеченні населення усіма видами соціальних гарантій. Враховуючи світовий досвід, можна стверджувати, що надання адміністративних послуг в закордонних країнах є відкритим та прозорим процесом, а в Україні досі немає таких ефективних взаємовідносин між споживачами та надавачами адміністративних послуг. Водночас варто зазначити, що практика закордонних країн спрямована на надання якісних адміністративних послуг протягом якомога коротшого часу при найменших затратах. А в Україні сьогодні найважливіше значення має дохідна частина держбюджету та джерела його наповнення.

Таким чином, зважаючи на світовий досвід, можна запропонувати певні шляхи покращення системи надання адміністративних послуг в Україні та пристосувати її до стандартів європейських країн. Так, на нашу думку, для цього Україні варто: розширити перелік адміністративних послуг у сфері соціального забезпечення та ЖКГ; розширити реєстр інституцій, які надають адміністративні послуги, включаючи не лише поодинокі органи державної влади та місцевого самоврядування, а й приватні заклади, шляхом надання дозволу на таку діяльність; зменшити розбіжності між адміністративними послугами та послугами, які надаються приватними суб’єктами; поглибити децентралізаційні процеси та делегувати права для прийняття рішень місцевим органам влади; ввести використання електронної форми надання адміністративних послуг; забезпечити довіру та безпеку споживачів адміністративних послуг, які отримують дану послугу в онлайн-режимі; покращити сервіси контролю за якістю надання адміністративних послуг, зважаючи на думку громадськості та безперервний контроль з боку публічних адміністрацій. На нашу думку, перспективою подальших досліджень є розкриття можливості введення у вітчизняну практику євростандартів е-врядування стосовно оцінки рівня якості надання адміністративних послуг.

\section{СПИСОК ВИКОРИСТАНИХ ДЖЕРЕЛ}

1. Андрєєва O.М. Електронне урядування країн Скандинавії: становлення та розвиток. Проблеми міжнародних відносин. 2014. Вип. 9. С. 154-168.

2. Васильєва Н.В. Досвід Естонії у наданні електронних послуг населенню. Державне управління:удосконалення та розвиток. 2013. № 11. URL: http:// nbuv.gov.ua/UJRN/ Duur_2013_11_5.

3. Жук Ю. Надання адміністративних послуг населенню: зарубіжний досвід. Ефективність державного управління. 2016. Вип. 1/2. С. 59-68.

4. Лахижа М.I. Удосконалення надання адміністративних послуг в Республіці Болгарія: ретроспективний аналіз. Публічне управління: теорія та практика. 2013. Вип. 4. С. 58-63.

5. Спасібов Д.В. Зарубіжний досвід інноваційних технологій надання публічних послуг. Вчені записки Таврійського начіонального університету імені В. І. Вернадського. 2018. № 1. С. 161-166.

6. Тимощук В. Адміністративні послуги : посібник. К. : ТОВ «Софія-А», 2012. 104 с.

7. Тихонова Д.С. Зарубіжний досвід надання адміністративних послуг органами публічної влади та можливості його використання в Україні. Право $i$ безпека. 2014. № 4. С. 70-75.

8. Туркова О.К. Надання електронних послуг в Естоніі: адміністративно-правовий аспект. Науковий вісник Міжнародного гуманітарного університету. 2016. Вип. 20. С. 60-62.

9. Циганов О.Г. Теорія адміністративних послуг та iii реалізація в країнах європейського союзу та в Україні. Юридичний науковий електронний журнал. 2017. № 5. С. 111-114.

10. Чечель А.О., Омельянович Р.А. Державне управління у сфері надання адміністративних послуг: європейський досвід. Право та державне управління. 2021. № 1. С. 279-284. 
11. Шкільняк М. Зарубіжний досвід управління муніципальною (комунальною) власністю. Рада: Інформаційно-методичний вісник Тернопільської обласної ради. 2003. № 7 (12). С. 87-88.

12. Nationaler Normenkontrollrat, E-Government in Deutschland: Wie der Aufstieg gelingen kann - ein Arbeitsprogramm (Kurzfassung), 2016, S. 5.

\section{REFERENCES}

1. Andrieieva, O.M. (2014). Elektronne uriaduvannia krain Skandynavii: stanovlennia ta rozvytok [E-government in Scandinavia: formation and development]. Problemy mizhnarodnykh vidnosyn - Problems of international relations, 9, 154-168 [in Ukrainian].

2. Vasylieva, N.V. (2013). Dosvid Estonii u nadanni elektronnykh posluh naselenniu [Estonia's experience in providing electronic services to the population]. Derzhavne upravlinnia: udoskonalennia ta rozoytok Public administration: improvement and development, 11. Retrieved from http://nbuv.gov.ua/UJRN/ Duur_2013_11_5[in Ukrainian].

3. Zhuk, Yu. (2016). Nadannia administratyvnykh posluh naselenniu: zarubizhnyi dosvid [Provision of administrative services to the population: foreign experience]. Efektyonist derzhavnoho upravlinnia - Efficiency of public administration, 1/2, 59-68 [in Ukrainian].

4. Lakhyzha, M.I. (2013). Udoskonalennia nadannia administratyvnykh posluh v Respublitsi Bolhariia: retrospektyvnyi analiz [Improving the provision of administrative services in the Republic of Bulgaria: a retrospective analysis]. Publichne upravlinnia: teoriia ta praktyka - Public administration: theory and practice, 4, 59-68 [in Ukrainian].

5. Spasibov, D.V. (2018). Zarubizhnyi dosvid innovatsiinykh tekhnolohii nadannia publichnykh posluh [Foreign experience of innovative technologies of public services]. Vcheni zapysky Tavriiskoho natsionalnoho universytetu imeni V.I. Vernadskoho - Scientific notes of Tavriya National University named after V.I. Vernadsky, 1,161-166 [in Ukrainian].
6. Tymoshchuk, V. (2012). Administratyoni posluhy [Administrative services]. Kyiv: TOV "Sofiia-A" [in Ukrainian].

7. Tykhonova, D.S. 92014). Zarubizhnyi dosvid nadannia administratyvnykh posluh orhanamy publichnoi vlady ta mozhlyvosti yoho vykorystannia v Ukraini [Foreign experience in providing administrative services by public authorities and the possibility of its use in Ukraine]. Pravo i bezpeka - Law and security, 4, 70-75 [in Ukrainian].

8. Turkova, O.K. (2016). Nadannia elektronnykh posluh v Estonii: administratyvno-pravovyi aspekt [Provision of electronic services in Estonia: administrative and legal aspect]. Naukovyi visnyk Mizhnarodnoho humanitarnoho universytetu - Scientific Bulletin of the International Humanities University, 20, 60-62 [in Ukrainian].

9. Tsyhanov, O.H. (2017). Teoriia administratyvnykh posluh ta yii realizatsiia $\mathrm{v}$ krainakh yevropeiskoho soiuzu ta $\mathrm{v}$ Ukraini [The theory of administrative services and its implementation in the countries of the European Union and in Ukraine]. Yurydychnyi naukovyi elektronnyi zhurnal - Legal scientific electronic journal, 5, 111-114 [in Ukrainian].

10. Chechel, A.O., \& Omelianovych, R.A. (2021). Derzhavne upravlinnia u sferi nadannia admiistartyvnykh posluh: yevropeiskyi dosvid [Public administration in the field of administrative services: European experience]. Pravo ta derzhavne upravlinnia - Law and public administration, 1, 279-284 [in Ukrainian].

11. Shkilniak, M. (2003). Zarubizhnyi dosvid upravlinnia munitsypalnoiu (komunalnoiu) vlasnistiu [Foreign experience in managing municipal (communal) property]. Rada: Informatsiino-metodychnyi visnyk Ternopilskoi oblasnoi rady - Council: Information and methodical bulletin of the Ternopil regional council, 7 (12), 87-88 [in Ukrainian].

12. Nationaler Normenkontrollrat (2016). E-Government in Deutschland: Wie der Aufstieg gelingen kann - ein Arbeitsprogramm (Kurzfassung) [in Deutschland]. 